\title{
COMMENTS
}

\section{Unearthing the Denominator in Regulatory Taking Claims}

\author{
John E. Fee†
}

In 1986, David Lucas purchased two beachfront lots on a South Carolina barrier island with the expectation of constructing single-family homes. His building plans violated no existing regulations. In fact, many of the neighboring parcels already had permanent homes similar to those Lucas wished to construct. Two years later, the South Carolina Legislature enacted the Beachfront Management Act, which prohibited the building of any permanent residential structures on the lots. Lucas's plans were completely frustrated, and the value of his two lots plummeted to almost nothing.

In Lucas $v$ South Carolina Coastal Council, the Supreme Court held that David Lucas had suffered a "taking" of his property for which the Fifth Amendment would guarantee him just compensation. ${ }^{1}$ The Court announced that although government may generally restrict the use of private property without compensation, a "taking" occurs when the regulation "denies all economically beneficial or productive use of land."

What the Court did not decide, however, is how to determine the relevant parcel of land that is subject to the regulatory

$\dagger$ B.A. 1992, Brigham Young University; J.D. Candidate 1995, The University of Chicago.

1112 S Ct 2886 (1992). The Fifth Amendment to the Constitution states: “. . . nor shall private property be taken for public use without just compensation."

${ }^{2}$ Lucas, $112 \mathrm{~S} \mathrm{Ct}$ at 2893 . Regulatory taking cases should not be confused with cases involving an actual physical invasion of the property. See Loretto $v$ Teleprompter Manhattan CATV Corp., 458 US 419 (1982). See also text accompanying note 40. 
taking inquiry. ${ }^{3}$ Suppose, for instance, that only one of Lucas's two parcels were subjected to the government regulation. Would there have been a taking of only that parcel? Or would the Court have analyzed the effect of the regulation on the two lots combined, finding that-because some economically beneficial use remained for the property as a whole-no taking had occurred?

Stated another way, the problem is defining the appropriate denominator in the regulatory taking "equation." Under Lucas, a court must compare the loss of property use resulting from a regulation, $x$, to the sum of all usage rights inherent in a piece of property, $y$. If $x / y$ equals 1 , then a taking has occurred; if $x / y$ is something less than one, the property owner is entitled to nothing. ${ }^{4}$ If the relevant property interest, $y$, is defined narrowly enough, as, for example, only those rights that have been regulated away, then a taking will always have occurred, rendering the Lucas test useless. ${ }^{5}$ On the other hand, if the relevant property interest is defined broadly enough, a regulatory taking will never occur. Determining the relevant parcel is not only an essential ingredient of the Lucas test, but indeed has proven one of the most difficult challenges in takings law. ${ }^{6}$

3 The Court stated: "Regrettably, the rhetorical force of our 'deprivation of all economically feasible use' rule is greater than its precision, since the rule does not make clear the 'property interest' against which the loss of value is to be measured." Lucas, 112 $\mathrm{S} \mathrm{C} t$ at $2894 \mathrm{n} 7$.

${ }^{4}$ If the regulation fails to prevent all economically viable use of a land parcel, there is no categorical taking under Lucas. Nevertheless, a court may find a taking to have occurred under a multifactor balancing test, considering a) the economic impact on the claimant, b) interference with the owner's reasonable investment-based expectations, and c) the government's interest in regulating. See Penn Central Transportation Co. $v$ New York City, 438 US 104, 124 (1977); Keystone Bituminous Coal Ass'n v DeBenedictis, 480 US 470, 485-97 (1987). In practice, however, landowners have rarely, if ever, prevailed in court on the basis of this balancing test alone. For a general discussion of the regulatory taking equation, see Frank I. Michelman, Property, Utility, and Fairness: Comments on the Ethical Foundations of "Just Compensation" Law, 80 Harv L Rev 1165, 1190-93 (1967).

This all-or-nothing test has been frequently criticized for its discontinuity in the treatment of various plaintiffs. See, for example, Lucas, 112 S Ct at 2919 (Stevens dissenting); Richard A. Epstein, Lucas v. South Carolina Coastal Council: A Tangled Web of Expectations, 45 Stan L Rev 1369, 1375-77 (1993).

- Consider a city ordinance prohibiting property owners from raising wild hogs on their property. If the relevant property interest, $y$, is defined as an easement to raise wild hogs, then the ordinance would constitute a taking, since it would prohibit all economically beneficial use of that easement.

Professor Epstein argues that all government restrictions on real property outside of the nuisance context constitute takings. See generally, Richard Epstein, Takings: Private Property and the Power of Eminent Domain (Harvard, 1985). The Supreme Court, however, has consistently rejected this approach.

6 Lucas was not the first case to raise the relevant-parcel problem, as the Supreme 
To determine the extent of a single parcel, courts have traditionally looked at factors such as whether land is contiguous, held by a common owner, or used for a single purpose, but they have usually made such decisions implicitly-without exploring the basis for their methodology. Courts have also applied these factors inconsistently, making regulatory taking determinations unpredictable and often arbitrary.

This Comment analyzes the problem of defining the relevant parcel, particularly as it applies to horizontal divisions of land.? Although property interests may be divided other ways-for example, vertically, ${ }^{8}$ temporally $^{9}$, or functionally ${ }^{10}$-the $\mathrm{Su}$ preme Court has more clearly resolved the denominator problem in those contexts. ${ }^{11}$ Section I examines the Supreme Court's jurisprudence concerning the denominator issue. Section II explores the various methods that lower courts have used to define the relevant parcel within the Supreme Court's parameters. Section III critiques these methods for defining the relevant parcel, all of which ineffectively resolve the denominator problem. Section IV proposes a new method of applying the Lucas test, focusing not on the property owner's actions or the extent of her ownership, but on the economic potential of the land itself. Under this standard, a taking has occurred when any horizontally definable parcel, containing at least one economically viable use independent of the immediately surrounding land segments, loses all economic use due to government regulation.

Court had for some time relied on diminution in value as a factor in regulatory takings. See, for example, Agins v Tiburon, 447 US 255, 262 (1980); Hodel v Virginia Surface Mining \& Reclamation Ass'n, Inc., 452 US 264, 295-96 (1981); Pennsylvania Coal Co. $v$ Mahon, 260 US 393, 413 (1922) ("One fact for consideration in determining such limits is the extent of the diminution."). A determination of the diminution in value depends on how the parcel of land in question is defined.

One commentator has suggested that Lucas will bring little change to the outcome of regulatory taking cases unless it signals a narrowing of the relevant parcel. See Note, The Effect of Lucas v. South Carolina Coastal Council on the Law of Regulatory Takings, 68 Wash L Rev 415 (1993).

7 This is the most common way of dividing property rights. It is meant to include any division into parcels, lots, or the like, as may be shown on a map.

8 The divisions of a parcel into air rights, surface rights, or subsurface rights are examples of vertical divisions of land.

This is the division of property interests into present and future estates.

10 This includes the division of property into easements, rights of way, servitudes, etc.

"While the Court has prohibited the vertical or functional severance of property rights, Penn Central, 438 US at 130-31; Keystone, 480 US at 500; Andrus v Allard, 444 US 51, 65-66 (1979), it has upheld a narrow view of the denominator when temporal divisions are at stake. First English Evangelical Lutheran Church v Los Angeles County, 482 US 304 (1987). 
Another way of characterizing this "independent economic viability" standard is that it gives property owners a limited freedom to define the relevant parcel in a way that constitutes a taking. The primary limitations on that freedom are: 1) the identified parcel must contain at least one economic or productive use independent of the surrounding land interests; and 2) the property may not be divided into uses, functions, or vertically defined interests. This approach would not only better conform to the purposes of both the Takings Clause and Lucas's "economically viable use" test, but would avoid many of the arbitrary and even discriminatory problems posed by alternative doctrines.

\section{SUPREME COURT JURISPRUDENCE ON THE TAKINGS DENOMINATOR}

\section{A. The Nonseverability Rule}

As a general rule, Supreme Court precedent requires courts to measure the effect of a given regulation on a whole parcel of land, and not on individual strands of property rights. A homeowner, therefore, who is prohibited from running a magazine stand on her front lawn does not have a valid taking claim simply because her right to run a magazine stand was completely extinguished through regulation. The need for such a rule is obvious if the Lucas test is to have any meaning. Unfortunately, commentators and courts have too frequently assumed that this is the end of the denominator issue,${ }^{12}$ when in fact two important questions remain unanswered. When does the nonseverability rule apply, and what constitutes a whole parcel?

Two Supreme Court cases, Penn Central Transportation Co. $v$ New York City ${ }^{13}$ and Keystone Bituminous Coal Ass'n $v$ DeBenedictis, ${ }^{14}$ provide important background for answering these questions. In Penn Central, the Penn Central Railway Company entered into a contract for the construction and lease of an office building above its Grand Central Station in New York City. Because the station was designated as a historic landmark, Penn Central was required to obtain authorization from the city's

12 See, for example, John A. Humbach, "Taking" The Imperial Judiciary Seriously: Segmenting Property Interests And Judicial Revision of Legislative Judgments, 42 Cath U L Rev 771, 796 (1993) (contending that Justice Scalia's hypothetical in which a rural developer is deprived of all economically viable use of $90 \%$ of a tract, but retains use in the remaining $10 \%$, is clearly not a taking under the nonseverability rule).

13438 US 104 (1978).

14480 US 470 (1987). 
Landmarks Preservation Commission for the alteration. The Commission denied two alternate plans for the construction on the grounds that an office building of such magnitude would overwhelm the existing station and destroy its architectural appeal. $^{15}$

Penn Central filed suit in New York state court, claiming that the city's rejection of its building plans constituted a taking of private property without just compensation. The trial court held in favor of Penn Central, but the New York Appellate Division reversed. The New York Court of Appeals affirmed, avoiding consideration of whether any economically viable use remained for the station by expanding the denominator to include Penn Central's other real estate holdings in the city. ${ }^{16}$

The Supreme Court affirmed the New York Court of Appeals's decision, though without necessarily accepting the inclusion of Penn Central's additional real estate holdings into the analysis. ${ }^{17}$ The Court did, however, explicitly reject Penn Central's proposal to consider the air rights above the station independently from the existing structures. Writing for the majority, Justice Brennan explained:

“Taking" jurisprudence does not divide a single parcel into discrete segments and attempt to determine whether rights in a particular segment have been entirely abrogated. In deciding whether a particular governmental action has effected a taking, this Court focuses rather both on the character of the action and on the nature and extent of the interference with rights in the parcel as a whole-here, the city tax block designated as the "landmark site."18

Determining that Penn Central had failed to show that the station was deprived of all economic use, the Court held that there had been no taking. ${ }^{19}$

15 Penn Central, 438 US at 116-18.

${ }^{16}$ Id at 119-20. "[E] ven if the Terminal proper could never operate at a reasonable profit, some of the income from Penn Central's extensive real estate holdings in the area, which include hotels and office buildings, must realistically be imputed to the Terminal ...." Id at 121.

17 The Court noted the New York court's analysis without comment, id, but determined that no taking had occurred by looking at the effect on only the terminal. Id at 13638. In Lucas, the Court explicitly rejected the analysis of the New York Court of Appeals as "extreme" and "unsupportable." $112 \mathrm{~S} \mathrm{Ct}$ at $2894 \mathrm{n} 7$.

18 Penn Central, 438 US at 130-31.

19 Id at 138. The Court emphasized that Penn Central is not precluded from building smaller structures and that building rights are transferable to nearby property under 
A majority of the Supreme Court employed similar reasoning in Keystone, which considered the effect of Pennsylvania's Bituminous Mine Subsidence and Land Conservation Act on the property rights of mining companies. ${ }^{20}$ Under the Act, Pennsylvania's Department of Environmental Resources ("DER") issued regulations requiring $50 \%$ of the coal beneath certain protected structures to be kept in place to provide surface support. ${ }^{21}$ Keystone, which had purchased mining rights as well as waivers for any damage caused to the surface from mining, argued that this constituted a taking. In particular, Keystone argued that the regulations destroyed the value of the support estate, ${ }^{22}$ which was recognized under Pennsylvania law as a distinct and severable set of property rights. ${ }^{23}$

The Supreme Court held in a five-to-four decision that the regulation of Keystone's mining rights did not amount to a taking. ${ }^{24}$ Refusing to consider the support estate or portions of the mineral estate separately, the Court emphasized that takings jurisprudence must consider the "parcel as a whole." ${ }^{25}$ The Court also relied on a statement from its previous decision in Andrus $v$ Allard: "[W] $]$ here an owner possesses a full 'bundle' of property rights, the destruction of one 'strand' of the bundle is not a taking because the aggregate must be viewed in its entirety. ${ }^{\text {"26 }}$ The Court regarded Pennsylvania's recognition of a support estate as a "legalistic distinction" having no bearing on the analysis, and concluded no unlawful taking had occurred. ${ }^{27}$

The Keystone decision is especially striking because its facts are nearly identical to those in Pennsylvania Coal Co. $v$ Mahon,

New York zoning laws. Id at 137.

${ }^{20} 480$ US 470 .

${ }^{21}$ Id at 476-77.

22 The support estate constitutes the rights to the coal that holds the surface in place. When owned in conjunction with the surface estate, it gives the right to be free from surface damage caused by mining. When held by the owner of the mineral estate, it gives the right to cause such damage.

${ }^{23}$ Id at 500 . Keystone also unsuccessfully argued that the regulation unconstitutionally impaired the obligations of its contract. Id at 502.

24 Id at 501-02.

${ }^{25}$ Id at 497, quoting Penn Central, 438 US at 130-31.

${ }^{26}$ Keystone, 480 US at 497, quoting Andrus, 444 US at 65-66. In Andrus, the Court considered the effect of an ordinance prohibiting the sale of goods containing eagle feathers on merchants engaged in the trade of Indian artifacts. 444 US at 52-55. The Court held that since the owner could use the artifacts for display purposes and even charge admission, the objects had not been deprived of all economically viable use, but merely of their highest or best use. Id at 66 .

${ }^{27}$ Keystone, 480 US at 500. 
in which the Court held in favor of the property owner. ${ }^{28}$ Pennsylvania Coal, like Keystone, involved a Pennsylvania law restricting a coal company's ability to remove certain coal from the earth after it had purchased the mineral rights in question. ${ }^{29}$ Writing for the majority, Justice Holmes conceded that the mere diminution of property value due to government regulation does not necessarily constitute a taking. ${ }^{30} \mathrm{He}$ stated, however, that "[w] hen [the regulation] reaches a certain magnitude, in most if not in all cases there must be an exercise of eminent domain and compensation to sustain the act," and concluded that "if regulation goes too far it will be recognized as a taking." ${ }^{31}$ Although Justice Holmes did not discuss the property interest against which a court must inquire whether a regulation has gone "too far," he assessed the effect of the regulation on "certain coal" that Pennsylvania had rendered valueless, thus suggesting an extremely narrow view of the relevant parcel. ${ }^{32}$

Despite the factual similarity between Keystone and Pennsylvania Coal, the Keystone majority distinguished Pennsylvania Coal on two grounds. First, the legislation in Pennsylvania Coal was a private benefit statute, whereas the regulations in Keystone were issued for the public benefit. ${ }^{33}$ Second, the DER regulations did not make the mining of "certain coal" commercially impracticable as the earlier law had done. ${ }^{34}$ Justice Stevens further contended that "certain coal," as discussed in Pennsylvania Coal, did not mean individual pillars of coal, but rather the mining of a certain kind of coal. ${ }^{35}$ Despite Justice Stevens's efforts to distinguish Pennsylvania Coal, however, many consider the two decisions to be plainly inconsistent. ${ }^{36}$

${ }^{28} 260$ US 393 (1922).

29 The Pennsylvania Coal Company sold the surface rights of a large tract of land, reserving the right to mine coal. The buyer expressly assumed the risk of surface damage caused by mining. But in order to prevent damage to surface estates, the state of Pennsylvania subsequently passed legislation that substantially restricted the types and quantities of coal that could be mined in the state. Id at 412-13.

30 Holmes wrote: "Government could hardly go on if to some extent values incident to property could not be diminished without paying for every such change in the general law." Id at 413.

31 Id at 413-15.

32 "To make it commercially impracticable to mine certain coal has very nearly the same effect for constitutional purposes as appropriating or destroying it." Id at 414 . In a dissenting opinion, Justice Brandeis argued that the effect of the regulation should be measured against the value of the entire property, including the surface estate not owned by the coal company. Id at 419 .

${ }^{33}$ Keystone, 480 US at $485-86$.

34 Id at 493 .

35 Id at 498 .

36 See, for example, Lucas, $112 \mathrm{~S} \mathrm{Ct}$ at 2894 (referring to the two decisions as incon- 
Chief Justice Rehnquist dissented in Keystone, emphasizing that, from the property owner's perspective, regulations can cause "as complete [a loss] as if the [government] had entered upon the surface of the land and taken exclusive possession of it." A taking therefore occurs whenever "the government by regulation extinguishes the whole bundle of rights in an identifiable segment of property." According to the dissent, the twenty-seven million tons of coal that Keystone was no longer able to mine clearly constituted an "identifiable and separable property interest" worthy of Fifth Amendment protection. ${ }^{39}$

\section{B. Limits of the Nonseverability Rule}

Although the Supreme Court has established a general rule against the conceptual severance of property rights, the denominator issue remains unresolved for two reasons. First, the cases leave unclear in which contexts the nonseverability rule applies. Second, the Court has not articulated a method for defining the "parcel as a whole." Until these issues are resolved, courts must continue to confront the question: denial of all economically viable use of what?

1. Contexts in which the nonseverability rule is not applied.

The Supreme Court has refrained from invoking the nonseverability rule in two contexts: physical intrusions on land, and temporal divisions of land. In both of these contexts it has applied what amounts to a complete severability rule. In Loretto

sistent on the denominator issue); Mid Gulf, Inc. $v$ Bishop, 792 F Supp 1205, 1214 n 5 (D Kan 1992) (claiming that Pennsylvania Coal had been overruled); Richard A. Epstein, Takings: Descent and Resurrection, 1987 S Ct Rev 1, 4-5 (arguing that Keystone has the effect of "gutting, although not explicitly overruling," Pennsylvania Coal).

37480 US at 516, quoting United States $v$ Causby, 328 US 256, 261 (1946). This reasoning from the property owner's perspective seems to have been adopted by a majority of the Court in Lucas. $112 \mathrm{~S} \mathrm{Ct}$ at 2894 (addressing the issue from "the landowner's point of view").

33 Keystone, 480 US at 517 (Rehnquist dissenting).

${ }^{39}$ Id. Chief Justice Rehnquist also criticized the majority for failing to rely on state law in determining what constitutes a separable property right. Since Pennsylvania recognized the existence of a distinct support estate, he concluded the majority erred in failing to consider the Act's effect on the support estate. Id at 518-20.

Under Chief Justice Rehnquist's analysis, a State's recognition of an "estate" presumably would provide an outer limit to the relevant parcel, but would not preclude a narrower analysis where the property interest is separable and identifiable. Otherwise, Rehnquist's discussion of the twenty-seven million tons of unminable coal (which constituted only a part of the mineral estate) as a separate interest would be inconsistent with his discussion of state law. 
$v$ Teleprompter Manhattan CATV Corp., the Court held that when a physical invasion of private property is involved, a taking occurs no matter how small the affected land segment may be. ${ }^{40}$ In Loretto, a New York statute required the owner of a small apartment building to allow the installation of cable television wires and connection boxes on her building so her tenants could have access to cable television. ${ }^{41}$ Although the invasion consisted of two small cable boxes and the connecting wires, the Court held it to be a taking. ${ }^{42}$ Loretto therefore abandons the nonseverability principle in one class of regulatory takings.

The Supreme Court has also upheld the temporal severability of property rights. In First English Evangelical Lutheran Church $v$ County of Los Angeles, the Court held that a regulation depriving a property owner of all economically viable use for a limited identifiable time period constituted a temporary taking under the Fifth Amendment. ${ }^{43}$ The Church filed an inverse condemnation claim in California state court in response to an ordinance prohibiting construction on its property. The California Court of Appeal, however, affirmed the lower court's refusal to award monetary damages on the grounds that simply invalidating the statute would remedy the violation. ${ }^{44}$ The Supreme Court reversed, holding that mere invalidation of a statute would fail to remedy the temporary deprivation of use occurring between the time the ordinance took effect and the time it is invalidated. ${ }^{45}$ Chief Justice Rehnquist wrote for the majority, arguing that "temporary' takings which, as here, deny a landowner all use of his property, are not different in kind from permanent takings, for which the Constitution clearly requires compensation." ${ }^{46}$ First English establishes the principle that property rights may be severed into time shares with no apparent restrictions. Insofar as a landowner can show that the property rights of a given parcel have been completely extinguished for an identifiable period of time, a taking has occurred. ${ }^{47}$

40458 US 419 (1982). See also Lucas, 112 US at 2893 (stating that compensation is required for physical invasions, "no matter how minute the intrusion").

42458 US at 423.

42 Id at $435-41$.

482 US 304, 321-22 (1987).

4 Id at 307-09.

45 Id at 321.

46 Id at 318. See also San Diego Gas \& Electric Co. v San Diego, 450 US 621, 657 (1981) (Brennan dissenting) ("Nothing in the Just Compensation Clause suggests that 'takings' must be permanent and irrevocable.").

${ }^{47}$ Justice Stevens dissented from the majority opinion in First English for precisely 
Thus, an open question remains: Are horizontal groupings of property interests subject to the nonseverability rule of Penn Central and Keystone-both of which deal with the vertical severance of property-or to the complete severability rule of Loretto and First English?

\section{Defining the parcel as a whole.}

Even where the nonseverability rule unquestionably applies, ambiguity remains because the Supreme Court has provided little guidance as to what constitutes a "parcel as a whole," especially with respect to horizontal divisions of land. In Penn Central, the Court identified the "parcel as a whole" as "the city tax block designated as the landmark site," regulation in question should define the relevant parcel. The Court, however, did not explain how it had reached that result. Similarly, in Keystone, after quoting the abstract statements from Penn Central and Andrus concerning the "parcel as a whole" and the "complete bundle of property rights," the majority declined to comment on the application of these categories beyond the facts of the case. ${ }^{49}$

Justice Scalia explicitly discussed the unresolved status of the denominator question in Lucas:

Regrettably, the rhetorical force of our "deprivation of all economically feasible use" rule is greater than its precision, since the rule does not make clear the "property interest" against which the loss of value is to be measured. When, for example, a regulation requires a developer to leave $90 \%$ of a rural tract in its natural state, it is unclear whether we would analyze the situation as one in which the owner has been deprived of all economically beneficial use of the burdened portion of the tract, or as one in which the owner has suffered a mere diminution in value of the tract as a

this reason. He argued that the temporary taking rule is inconsistent with the Keystone and Penn Central admonition to consider the effect of a regulation on the parcel as a whole. First English, 482 US at 329-32. See also Margaret Jane Radin, The Liberal Conception of Property: Cross Currents in the Jurisprudence of Takings, 88 Colum L Rev 1667, 1676 (1988) (claiming that the Court's approach in First English was an exercise in "conceptual severance").

48 US at 131.

49 Keystone, 480 US at 497-501. Justice Stevens wrote: "Although these verbal formulations do not solve all of the definitional issues that may arise in defining the relevant mass of property, they do provide sufficient guidance to compel us to reject petitioners' arguments." Id at 497. 
whole .... The answer to this difficult question may lie in how the owner's reasonable expectations have been shaped by the State's law of property-i.e., whether and to what degree the State's law has accorded legal recognition and protection to the particular interest in land with respect to which the takings claimant alleges a diminution in (or elimination of) value. In any event, we avoid this difficulty in the present case, since the "interest in land" that Lucas has pleaded (a fee simple interest) is an estate with a rich tradition of protection at common law, and since the South Carolina Court of Common Pleas found that the Beachfront Management Act left each of Lucas's beachfront lots without economic value. ${ }^{50}$

Not only does this dictum practically invite lower courts to experiment with the denominator issue, but it also suggests a relatively narrow definition of the relevant parcel. As several commentators have noticed, this footnote bears a striking resemblance to the Keystone dissent. ${ }^{51}$ The Court not only notes the inconsistency between Keystone and Pennsylvania Coal regarding the denominator issue, but suggests the common law methodology expressly rejected in Keystone. ${ }^{52}$

The Supreme Court has thus failed to provide clear guidance to courts on the denominator question-especially in horizontal cases. Not only has the Court never decided a case involving the horizontal division of land, but it has failed to define "parcel as a whole." Until this issue is resolved, lower courts will continue to face the crucial question: economically viable use of what land?

\section{LOWER COURT FORMULATIONS OF THE RELEVANT PARCEL}

Lower courts-especially the United States Court of Federal Claims ${ }^{53}$-have encountered the problem of horizontally grouping and separating property interests with some regularity. Instead of employing a consistent methodology, however, the courts have used a variety of fact-specific and often inconsistent methods to define the relevant parcel. The various approaches to defining the relevant parcel may be grouped into three categories:

so $112 \mathrm{~S} \mathrm{Ct}$ at $2894 \mathrm{n} 7$.

51 See, for example, Note, 68 Wash L Rev at 433 (cited in note 6).

${ }^{62}$ See Note, "Property" in the Fifth Amendment: A Quest for Common Ground in the Maze of Regulatory Takings, 46 Vand L Rev 1283, 1309 (1993).

s3 In 1992, the United States Claims Court was renamed the United States Court of Federal Claims. 
1) contiguous land under a common owner; 2) multifactor analysis based on reasonable expectations; and 3) the property interest defined by the regulation or development proposal.

\section{A. Contiguous Land under a Common Owner}

A common method of isolating a bundle of property interests for regulatory takings analysis is to consider all contiguous property under a common owner as a single, indivisible parcel. This method of defining the relevant parcel, however, is more often an unstated assumption than a carefully chosen methodology. Indeed, a number of courts seem to have implicitly employed this uniformity-of-ownership definition without even evaluating the propriety of other rules. ${ }^{54}$

Courts employing this standard have divided over whether contiguous property previously owned by the landowner may be considered, or whether only property owned at the moment of the regulation should form part of the relevant parcel. For instance, in Deltona Corp. $v$ United States, Deltona purchased a ten-thousand-acre parcel on the Florida Gulf coast for the purpose of developing twelve thousand single family tracts. ${ }^{55}$ Deltona divided the parcel into five permit areas. It successfully obtained the requisite permits, and developed and sold the individual tracts in one area, but the Army Corps of Engineers denied several requests for the development of two other areas. ${ }^{56}$ The Court of Federal Claims held that the relevant parcel included the whole ten-thousand-acre tract originally purchased by Deltona, despite the fact that it no longer owned all ten thousand acres. ${ }^{57}$

\section{B. Multifactor Analysis Based on Reasonable Expectations}

Although the contiguous-land-under-a-common-owner test is relatively easy to apply, courts have often abandoned its strict

st See, for example, Bevan v Brandon Township, 438 Mich 385, 475 NW2d 37, 43 (1991); Jones $v$ Town of McCandless, 134 Pa Commw 435, 578 A2d 1369, 1371-72 (1990); Jentgen $v$ United States, 657 F2d 1210, 1213 (Ct Cl 1981). Compare Corrigan v City of Scottsdale, 149 Ariz 553, 720 P2d 528, 538 (1985) (holding that a zoning ordinance that affects one of several contiguous parcels will only be considered in light of its effect on the combined parcel).

ss 657 F2d 1184 (Ct Cl 1981).

36 Id at $1188-89$.

${ }^{37}$ Id at 1191-94. For the opposite approach from the same court, see Loveladies

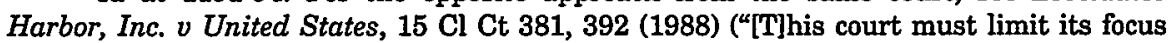
upon the value of that property which plaintiffs held when the taking was said to have occurred."). 
application when other factors point toward grouping the parcels differently. Among the factors on which courts have relied are whether the owner uses the property for a common purpose, whether the land was purchased at the same time, whether there are one or several tax deeds on the land, whether the owner considers his various lots as separate entities, and general considerations of fairness. The Court of Federal Claims's discussion of the issue in Ciampitti $v$ United States is typical:

Factors such as the degree of contiguity, the dates of acquisition, the extent to which the parcel has been treated as a single unit, the extent to which the protected lands enhance the value of remaining lands, and no doubt many others would enter the calculus. The effect of a taking can obviously be disguised if the property at issue is too broadly defined. Conversely, a taking can appear to emerge if the property is viewed too narrowly. The effort should be to identify the parcel as realistically and fairly as possible, given the entire factual and regulatory environment. ${ }^{58}$

Relying on multiple factors instead of simply contiguity and unity of ownership can lead to either a broader or a narrower definition of the relevant parcel. For instance, in American Savings \& Loan Ass'n $v$ Marin County, the Ninth Circuit held that two adjacent parcels under a common owner should be considered separately if it could be shown that the owner treated the two parcels separately. ${ }^{59}$ In Ciampitti, however, the Court of Federal Claims held that when a developer purchases two noncontiguous lots as part of a single transaction, and treats those lots as one for financing purposes, they may form a single parcel for takings purposes. ${ }^{60}$

C. The Property Interest Defined by the Regulation or Development Proposal

A final category of lower-court opinions focuses on the nature of the state's regulatory action to define the relevant parcel. In Twain Harte Associates, Ltd. $v$ Tuolumne County, a county ordinance rezoned a 1.7-acre portion of an 8.5-acre parcel as "open space," severely limiting the uses to which that portion could be

s8 $22 \mathrm{Cl} \mathrm{Ct} \mathrm{310,318-19} \mathrm{(1991).}$

s9 653 F2d 364, 372 (9th Cir 1981).

so $22 \mathrm{Cl} \mathrm{Ct}$ at 320 . For a description of the New York Court of Appeals's similarly expansive approach in Penn Central, see text accompanying note 16. 
put. $^{61}$ Rather than consider the regulatory effect on the entire 8.5 acre parcel, for which there remained some economic potential, the court focused on the 1.7-acre segment. The court stated that "the nature of a particular land use regulation" may have the effect of "creating separate parcels for "taking' purposes."62 To obtain a summary judgment against the owner, therefore, the county was required to demonstrate that:

(i) the 1.7-acre plot was not economically viable apart from the larger parcel; (ii) some development would be allowed on the 1.7-acre plot; or (iii) it would grant compensating densities or other allowances on the larger, 6.8-acre shopping center parcel, in order to ameliorate the owners' loss of development options with respect to the smaller, 1.7-acre parcel. $^{63}$

The Twain Harte approach therefore focuses less on the owner's relationship to the property and more on the regulation itself to identify the relevant parcel. This is evident both through the claim that a regulation can create a separate parcel, and the inquiry as to whether the 1.7-acre parcel was economically viable apart from the larger unit. ${ }^{64}$

The Federal Circuit and the Court of Federal Claims have employed a similar approach in cases where the alleged regulatory taking arises from the government's rejection of an owner's proposal to develop a portion of his property or extract its resources. These courts have ruled that when the reviewing governmental body considers and rejects the proposed use of only a portion of the owner's property, and when it appears highly likely that similar proposals for the other segments of property would also be rejected, the court should focus only on the portion defined in the rejected proposal.

Thus, in Florida Rock Industries, Inc. $v$ United States, the court held that the government's refusal to allow limestone mining on a proposed 98-acre tract constituted a taking of those 98 acres even though the tract was only part of the owner's original

61 217 Cal App 3d 71, 265 Cal Rptr 737, 739-40 (1990).

62 Id at 744-45.

63 Id at 745.

64 Nevertheless, the court implicitly uses common ownership and contiguity as a starting point in the analysis, and then uses other considerations to narrow the analysis. Other cases adopt a similar approach for zoning laws. See Keith v Town Council, 1992 Conn Super LEXIS 1778; Fifth Avenue Corp. $v$ Washington County, 282 Or 591, 581 P2d 50 (1978). 
1,560-acre purchase. ${ }^{65}$ The court reasoned that, given the unlikelihood a similar proposal would be approved for another segment, it would be unjust to consider the possible uses of the full 1,560 acres in the analysis. ${ }^{66}$

The Federal Circuit did not hold, however, that the entire 1,560 acres had been stripped of all economically viable use. Instead, it excluded from the analysis those acres for which the plaintiff had not submitted a proposal, reasoning that the government might now approve future mining proposals in light of the court's decision that the 98 acres had been taken. ${ }^{67}$ The distinction is significant, for although the plaintiff's damages were limited to compensation for the 98 acres, the Florida Rock decision gives property owners a greater degree of control in defining the relevant parcel. A property owner anticipating litigation might submit a proposal involving a certain segment of property for which there is no other economically viable use. If the proposal is denied, and it appears that similar proposals would be denied for the owner's contiguous land interests, the landowner would receive compensation for the segment defined by his proposal even if the contiguous property has other potential but unrelated uses.

The Court of Federal Claims used a similar approach in Loveladies Harbor, Inc. $v$ United States, holding that the denial of a proposal to develop 12.5 acres pursuant to federal wetlands regulation could constitute a taking, even though the owner's original 250-acre purchase included economically viable land outside of the area designated as wetlands. ${ }^{68}$ Using the Florida Rock principle, the court first excluded from the analysis the owner's wetland holdings not mentioned in the proposal. The court then excluded the nonwetland holdings from the analysis, for they were no longer adjacent to the 12.5 acres in question and therefore could not be considered part of the same parcel. ${ }^{69} \mathrm{Al}-$ though Loveladies Harbor may appear rather formalistic, it seems to represent a trend in the Court of Federal Claims toward giving property owners greater control in defining the relevant parcel..$^{70}$

65 791 F2d 893, 904 (Fed Cir 1986), vacated on other grounds, 18 F3d 1560 (Fed Cir 1994).

${ }_{66}$ "We do not think that the mere possibility a permit might be granted, like the possibility one might put a pot of water on a hot stove and have it freeze, is a reality requiring us to deem that viewing the 1,560 acres as a whole, Florida Rock might in theory mine a lot of limestone, or perhaps market a housing development as appellant also would have us speculate." Id.

67 Id at 904-05.

$\$ 15 \mathrm{Cl} \mathrm{Ct}$ at $391-93,399$.

69 Id at 392-93.

70 But see Ciampitti, $22 \mathrm{Cl} \mathrm{Ct}$ at 320 (holding that two noncontiguous segments of 


\section{ANALYSIS OF VARIOUS CRITERIA FOR IDENTIFYING THE RELEVANT PARCEL}

Any regulatory taking test that focuses on the diminution in value or viable use of property would be useless if it did not limit the litigant's ability to sever those rights into increasingly smaller units. Without such a limitation, a property owner could always define the relevant interest as precisely those rights that were abrogated-a complete negative easement in every case. ${ }^{71}$ The need for such a limitation is fully evident; what scholars often overlook, however, is that any test must also prevent the state from defining the parcel as broadly as it wishes.

Although both scholars and courts have made sweeping statements against the "conceptual severance" of property rights, they necessarily assume some set of "severing" criteria to separate one parcel from another. ${ }^{72}$ Otherwise, the entire world would constitute the only "parcel as a whole." These severing criteria, though usually implicitly assumed by courts and commentators, should come to the fore if a fair and rational formulation of the relevant parcel is to be achieved. Three of the most common sets of criteria used are: unity of ownership, actions or expectations of the owner, and government-controlled criteria. ${ }^{73}$

\section{A. Unity of Ownership}

The most common criterion for horizontally isolating one parcel of property rights from all others focuses on where one owner's property rights end and the next owner's property rights begin. Indeed, even the narrower methodologies employed in Twain Harte, Florida Rock, and Loveladies Harbor employ unity of ownership and contiguity as starting points in the analysis. ${ }^{74}$

land must be viewed as a whole since they were purchased and financed together).

${ }^{71}$ This aspect of the diminution-in-value test has been discussed for years. See, for example, Michelman, 80 Harv L Rev at 1190-93 (cited in note 4); Joseph L. Sax, Takings and the Police Power, 74 Yale L J 36, 60 (1964).

${ }_{72}$ Consider the Court's statement in Andrus that "where an owner possesses a full 'bundle' of property rights, the destruction of one 'strand' of the bundle is not a taking, because the aggregate must be viewed in its entirety." 444 US at 65-66. This statement necessarily depends on some separating criteria for distinguishing one bundle from another.

${ }^{73}$ Although these analytical categories generally correspond to the three current methodologies previously discussed (contiguous land under a common owner, the multifactor analysis, and the property interest defined by the regulation or development proposal), the parallel is not exact. Most notably, unity of interest, while particularly central to the contiguous-land-under-a-common-owner methodology, is invoked under the other approaches as well. The discussion of that criterion, therefore, is relevant to all three lower-court methodologies.

74 See, for example, Loveladies Harbor, $15 \mathrm{Cl} \mathrm{Ct}$ at 391.93 (beginning the analysis 
The most obvious virtues of a unity-of-ownership criterion are that it is easy to employ and that its application often reflects an intuitive sense of what constitutes a "parcel" of land. ${ }^{75}$ Despite these strengths, unity of ownership is a problematic criterion for defining a parcel of property for several reasons.

First, as a conceptual matter, the unity-of-ownership criterion fails to give property the full value of the sum of all its parts. Consider Ciampitti, in which a developer purchased an area of wetlands and a parcel of noncontiguous upland territory in a single transaction. ${ }^{76}$ The court's decision to analyze the owner's combined interest as one parcel effectively rendered both the wetlands and the uplands less valuable than if they had been purchased by different individuals. Such a system not only violates the standard assumption of property as a fungible and consistent set of entitlements, ${ }^{77}$ but it could also lead to perverse incentives on the part of landowners. For example, knowing what he now knows about the law, Robert Ciampitti probably would have purchased the uplands or the wetlands, but not both. Instead, he might have devised a contractual arrangement whereby another person would hold title to part of the land, but Ciampitti would develop it, bearing both the risks and profits of the enterprise. Alternatively, if the transaction costs of such an arrangement were preclusive, he may have simply developed less land, leaving the remainder to a less efficient developer or no developer at all. Under either scenario, an inefficient allocation of resources results, so as to increase the likelihood of compensation for future regulations.

Justice Brandeis emphasized this weakness in his dissenting opinion in Pennsylvania Coal:

The rights of an owner as against the public are not increased by dividing the interests in his property into surface and subsoil. The sum of the rights in the parts can not be

with the 250 acres originally purchased by the owner, then narrowing the focus within those $\mathbf{2 5 0}$ acres).

75 Although land could be conceptually separated into parcels for any conceivable purpose, it seems that in the modern world it is often done to distinguish ownership. Consequently, what the average person thinks of as a "parcel" of land often has the distinguishing characteristics of a deed, a common owner, and a surveyed boundary beyond which ownership changes. There is nothing inherent in the word "parcel," however, which prevents a single person from owning two separate parcels side by side, or from several individuals owning various parts of a single parcel.

${ }^{76} 22 \mathrm{Cl} \mathrm{Ct}$ at 311-13.

77 For a thorough discussion of this aspect of the denominator problem, see Epstein, Takings at 57-62 (cited in note 5). 
greater than the rights in the whole.... I suppose no one would contend that by selling his interest above one hundred feet from the surface he could prevent the State from limiting, by the police power, the height of structures in a city. And why should a sale of underground rights bar the State's power? ${ }^{78}$

Although the issue in Pennsylvania Coal involved a vertical division of land, the problem identified by Justice Brandeis is no different in the horizontal context. If an owner cannot limit the power of the state by selling his air or underground rights, why should he be able to do so by selling horizontally adjacent property rights? The common-ownership standard creates just such a system. $^{79}$

Another problem with the common-ownership standard is that it arbitrarily discriminates against those who happen to have a larger group of property rights in a single place. Some claim that this turns the diminution-in-value test into a deeppocket rule, forcing extensive holders of property to suffer a greater loss in property rights to maintain a valid taking claim. ${ }^{80}$ But this understates the problem. The outcomes under this standard are often arbitrary, denying compensation to those with less wealth as well as to those with more. For example, suppose that five individuals each own equally sized beachfront lots. In addition, they each own private homes. But whereas the first four owners live across town, the fifth has her home on a lot directly behind her beach lot. If a regulation were enacted restricting all viable use of the beachfront property, the first four would be compensated while the fifth might not. ${ }^{81}$ If a deeppocket rule is intended, would not an inquiry into the owner's assets, liabilities, and income stream be more appropriate?

78260 US at 419 (Brandeis dissenting). At least one lower court has followed Justice Brandeis's reasoning in Pennsylvania Coal. See Mid Gulf, Inc. v Bishop, 792 F Supp 1205, 1214 (D Kan 1992) (holding that the complete abrogation of an oil and gas lease does not effect a taking where surface rights remain viable, even though those surface rights are owned by a different party).

79 See also Carol M. Rose, Mahon Reconstructed: Why The Takings Issue Is Still a Muddle, 57 S Cal L Rev 561, 568 (1984) ("This approach may cause owners to make elaborate and socially useless splits of their property rights, so that any one property right affected by a regulation is completely taken, and the courts will have to reunite the bundle of property rights to determine whether there truly has been a taking.").

${ }^{80}$ See id.

81 For similar examples demonstrating the arbitrariness of ownership as a criterion, see Michelman, 80 Harv L Rev at 1234 (cited in note 4). 
Failure by most courts to even recognize these problems, let alone justify them, makes one suspicious of unity of ownership as a factor in defining the relevant parcel. One unspoken intuition that may have led courts to rely on unity of ownership is the notion that those with more property are harmed less when some of it is devoted to public use. However, the Takings Clause does not set a minimum level of harm that one must have suffered to receive just compensation. It simply states a principle that the government pays for what it takes.

Alternatively, the unity-of-ownership rule might be justified on the grounds that it redistributes wealth. Corporations and wealthy individuals are more likely to lose taking claims under a unity-of-ownership standard, because they are more likely to own large, indivisible tracts of land. The benefits of government regulation, on the other hand, would benefit everyone equally, thus effecting a net transfer of benefits from those who have more to those who have less.

Given the numerous alternative means of redistributing wealth, however, interpretation of the Takings Clause is an inappropriate means of accomplishing this goal. First, takings jurisprudence cannot ensure an even and equitable transfer of wealth. Although a unity-of-ownership standard would effect a net transfer of benefits from the wealthy to the poor, individual cases would vary widely. Many wealthy individuals and corporations have only small and scattered real estate holdings, whereas relatively poor individuals, like some farmers and ranchers, may own large, contiguous quantities of land. The effects of regulation are also extremely unpredictable and inequitable, affecting some individuals severely and others not at all. Finally, courts should leave the task of implementing and carrying out redistributive goals to politically accountable legislators and executive officials whose constituencies are relatively broad based. Although some politically accountable body, such as a zoning board, must promulgate a redistributive regulation before it can ever be challenged in court, it is precisely this form of hidden redistribution that should be suspect under the Takings Clause. Many regulations, especially the discretionary decisions of zoning boards, harm only a few politically powerless individuals while the benefits may flow to many. The local political process, therefore, rather than checking potential redistributive abuses, may only add fuel to the fire. ${ }^{82}$

82 In fact, government policies of this sort seem to be precisely what the Takings 


\section{B. Subjective Belief of the Owner}

Other criteria used by the courts to define the relevant parcel measure the actions or expectations of the owner to distinguish one parcel from another. These may include an owner's actual use of property, her intended use, or a number of other actions or expectations that indicate that she actually considers a certain portion of property to be a separate and distinct parcel. Although the use of these criteria will sometimes avoid problems created by the unity-of-ownership standard, ${ }^{83}$ such use would lead to similar arbitrary and unfair results. ${ }^{84}$

For example, an owner who purchases two one-acre lots with the intention of building a home on one lot and an office building on the other would likely be compensated if all development were prohibited on the office lot. However, if the same owner instead purchases the lots intending to build a two-acre office complex over both, he would not be entitled to compensation, even if his second choice would have been to build a home and an office building as in the first case. Ironically, the owner loses more in the second scenario-for he loses both his best and second-best uses of the office lot-but is entitled to nothing by way of compensation.

Perhaps in an effort to avoid such results, courts have sometimes jumbled these subjective factors along with others into an ad hoc test, deciding each case without committing to any explicit rule of decision. Although ad hoc decision making has traditionally played an important role in regulatory taking claims, the Supreme Court intentionally avoided this approach in Lucas by announcing a "rule" of "categorical treatment" where an owner has lost all economically beneficial use of his property. ${ }^{85}$ This categorical rule, however, would break down if the denominator inquiry were to depend completely on a set of ad hoc criteria. An ad hoc approach would easily mask the prejudices of individual

Clause is designed to correct, either by preventing the government action in the first place or by ensuring "just compensation." See Rose, $57 \mathrm{~S} \mathrm{Cal} \mathrm{L} \mathrm{Rev} \mathrm{at} \mathrm{581-82} \mathrm{(cited} \mathrm{in} \mathrm{note} \mathrm{79)}$ (arguing that Holmes's decision in Pennsylvania Coal is designed to curb redistribution).

${ }_{83}$ For example, in the hypothetical variation on Ciampitti discussed in the text following note 77, the owner of the wetlands would not be able to avoid inclusion of the uplands in the analysis simply by formally vesting title in another person.

${ }^{34}$ The unity-of-ownership criterion may in fact be considered part of the larger category of the owner's subjective belief, insofar as it depends on the owner's choice to buy or sell property prior to the regulation.

85 $112 \mathrm{~S}$ Ct at 2893-94. But see Justice Stevens's dissent, id at 2918-19 (objecting to the majority's adoption of a "categorical rule" in regulatory taking cases). 
judges. Moreover, whatever factors or ideologies motivate a court's decision, a system based on the rule of law would require that such criterion be open and explicit. Both government and property owners could then act with a clear understanding of their rights and obligations under the Constitution.

\section{Government-Controlled Criteria}

A third category of criteria for horizontally distinguishing property rights looks to the government's actions rather than those of the owner. Some courts, for example, have implied that the ordinance or regulation affecting the property in question should be determinative in defining the relevant parcel. Such an approach, however, should be highly suspect since it is the government that is constrained by the Takings Clause. In Twain Harte ${ }^{86}$ for example, the government might have worded its regulation carefully so as to avoid Fifth Amendment liability. Rather than simply zoning the 1.7 acres as open space, creating a separate parcel, it could have enacted a comprehensive zoning scheme for the entire 8.5-acre "parcel," disallowing development on the 1.7-acre "portion," but explicitly allowing for some "economic" use of the remainder. Courts could attempt to guard against such abuses, but only through reliance on some external standard to judge the government's regulatory definitions of property. If another standard is necessary to determine what constitutes a just division, it is better to use that standard in the first instance.

Another approach based on government-controlled criteria was suggested by the majority in Lucas:

The answer to this difficult question may lie in how the owner's reasonable expectations have been shaped by the State's law of property-i.e., whether and to what degree the State's law has accorded legal recognition and protection to the particular interest in land with respect to which the takings claimant alleges a diminution in (or elimination of) value. ${ }^{87}$

The Lucas majority, however, does not elaborate on this proposal or on how a state's common law could be used to distinguish a bundle of rights horizontally. One possibility is that any interest recognized as an "estate" at common law could constitute a sin-

86265 Cal Rptr 737. See text accompanying notes 61-64.

87112 S Ct at 2894 n 7. 
gle, indivisible parcel for takings purposes. This interpretation, however, fails to resolve difficult cases, such as when a developer buys a large tract of land and subsequently divides it into multiple lots for resale. The question whether the developer owns one estate or many is no clearer than the question whether there is one parcel or many.

Rather than relying on formalistic labels such as "estates" to resolve the issue, one might interpret Justice Scalia's dictum as suggesting analysis of the property owner's rights under common law. Specifically, one would inquire whether the common law allows a particular set of property rights to be severed and traded as an independent unit. This appears to be Chief Justice Rehnquist's suggestion in his Keystone dissent. ${ }^{88}$ The application of this principle is easier to grasp in the vertical Keystone context-where Pennsylvania allowed a support estate to be severed from the surface and mining estates-than in the horizontal context. Under most common law regimes, one may legally sever any horizontally identifiable segment of an estate and sell it, thereby creating two estates from one. If the common law "right to sever" were determinative of the regulatory taking denominator, then a property owner alleging a taking could horizontally define the relevant parcel as narrowly as she chose. Although conceptually sound, this rule could lead to extremely costly results in a modern regulatory state. Virtually all set-back ordinances, which restrict how close to the street a property owner may build, would be unconstitutional without compensation. ${ }^{89}$ As Justice Holmes wrote in Pennsylvania Coal: "Government hardly could go on if to some extent values incident to property could not be diminished without paying for every such change in the general law."90 Although this rule as applied to horizontal divisions of land would not go quite so far as to require compensation for any diminution in value, its costs would nevertheless be extraordinary. It seems unlikely that even Justice Scalia would go so far. Rather, one wonders whether he simply borrowed the suggestion of employing a common law analysis from

${ }^{88}$ "In these circumstances, where the estate defined by state law is both severable and of value in its own right, it is appropriate to consider the effect of regulation on that particular property interest." 480 US at 520 .

${ }^{89}$ The Supreme Court upheld the validity of set-back ordinances against taking claims in Gorieb v Fox, 274 US 603, 610 (1927).

${ }^{90} 260$ US at 413. See also Jed Rubenfeld, Usings, 102 Yale L J 1077, 1159 (1993) ("The price of simplicity would be extremely high."). 
the Keystone dissent without fully considering how it would apply to horizontal divisions of land.

\section{RECONCEPTUALIZING THE DENOMINATOR}

Through reliance on the subjective criteria of ownership and actual or intended use, courts have gone astray. The regulatory taking inquiry should instead focus on whether the property interest proposed to have been taken is in fact substantial enough to warrant Fifth Amendment protection as an independent bundle of rights. Although different methods of measuring the substantiality of a property interest could be devised, it seems that the most logical method would depend on its economically productive potential as an independent unit. This Comment therefore proposes the following rule for horizontal divisions of land: any identifiable segment of land is a parcel for purposes of regulatory taking analysis if prior to regulation it could have been put to at least one economically viable use, independent of the surrounding land segments.

Under this test, the task of a court would not be to determine which division of land is the correct parcel, as if there were only one correct answer. Instead, a court would begin with the plaintiff's assertion that a particular parcel of land had been taken, examining the parcel to see if it could have been put to at least one economically viable use independent of the surrounding land prior to the regulation. If so, the court would determine whether the parcel had been deprived of all economically viable use through government regulation. The plaintiff would seek to define a parcel broadly enough to show that prior to regulation the parcel contained an economically viable use independent of the surrounding property interests, but he would also seek to define the parcel narrowly enough to prove that no economically viable use remains.

This standard of independent economic viability grants owners the central role in defining the parcel to be analyzed by the court. Although some commentators have resisted granting the owner such control, ${ }^{91}$ they assume that such a role would be unlimited-that an owner could identify the relevant property inter-

91 See Radin, 88 Colum L Rev at 1674-78 (cited in note 47); Frank Michelman, Takings, 1987, 88 Colum L Rev 1600, 1614-21 (1988); Essay, Takings: The Fifth Amendment, Government Regulation, and the Problem of the Relevant Parcel, $8 \mathrm{~J}$ Land Use \& Envir L 381, 402 (1993). 
est as exactly those rights that had been extinguished by regulation. ${ }^{92}$

Under a rule of substantiality, however, the ability of the owner to define the parcel would be limited in two important ways. First, the rule would apply only to horizontal divisions of land. Under clear Supreme Court precedent, a property owner would have no authority to divide property rights into uses, easements, servitudes, or the like. ${ }^{93}$ In addition, under the authority of Penn Central and Keystone, courts must consider all air, surface, and subsurface rights of a particular parcel as a single bundle of property rights. ${ }^{94}$ That a different rule would apply for horizontal divisions of land, however, is not surprising-for there, the nonseverability rule cannot apply in the same absolute way that it does in the vertical and functional contexts. Once the horizontal limits of a "parcel" are determined, one can logically say that it extends from the center of the earth to the heavens, and to every conceivable use thereof. ${ }^{95}$ But one cannot push the nonseverability rule to its absolute limit in the horizontal dimension, or all property would blur into one. As has been previously discussed, courts need some further set of criteria to define a parcel horizontally.

Another important limitation on the owner's ability to define a parcel as a whole is the requirement of substantiality. For any given section of land to constitute a legitimate "parcel," it must be shown that there existed prior to regulation at least one economically viable use for the land, the value of which is derived independently of the immediately surrounding land interests.

\section{Radin's treatment of the issue is typical:}

[W] must observe that as soon as one adopts conceptual severance ... there is an easy slippery slope to the radical Epstein position. Every curtailment of any of the liberal indicia of property, every regulation of any portion of an owner's "bundle of sticks," is a taking of the whole of that particular portion considered separately.

Radin, 88 Colum L Rev at 1677-78 (cited in note 47).

${ }_{93}$ See, for example, Andrus, 444 US at 65-66 (holding that a restriction on the sale of certain items is not a taking because "the destruction of one 'strand' of the bundle is not a taking"). See also Lucas, $112 \mathrm{~S} \mathrm{Ct}$ at $2895 \mathrm{n} 8$ ("It is true that in at least some cases the landowner with $95 \%$ loss will get nothing, while the landowner with total loss will recover in full.").

${ }_{94}$ Penn Central, 438 US at 130 (air rights); Keystone, 480 US at 497 (subsurface rights).

${ }_{95}$ This Comment assumes that vertical and functional severability are not allowed even when there is a difference in ownership. The issue, however, has not been resolved in the courts, and rarely arises. 
This limitation has two parts. The first, requiring that the parcel contain at least one economically viable use prior to the regulation, follows directly from the Lucas test. If the land had no economically viable use prior to the regulation, then a regulation cannot be said to have deprived the owner of all such use. The second part of this limitation, requiring the proposed use to derive its economic value independently of the immediately surrounding land interests, is a less obvious but nevertheless important element in limiting the range of legitimate parcels. In many situations, an identifiable segment of land may be put to no economically viable use, other than to expand or beautify a building or business operation existing on a neighboring segment of land. The most obvious example of this is the property between the edge of a building and the street. In most situations, this buffer zone would be of no economic use to anyone except the owner of the building, and the owner of the building typically would have no economic use for it other than to plant grass, expand the existing enterprise, or otherwise add value to a larger segment of land. In such a case, it would be inappropriate to consider the buffer zone an independent parcel for regulatory taking purposes, for it has no economic use in and of itself. ${ }^{96}$

If this limitation did not apply, then owners disadvantaged by a set-back ordinance could almost always maintain successful inverse condemnation claims. That would not only violate longstanding Supreme Court precedent upholding the presumed validity of set-back ordinances, ${ }^{97}$ but would also cause an enormous upset in well-settled expectations.

Under the proposed standard, a set-back ordinance would not require compensation unless one of two conditions were met. If the ordinance is so restrictive as to make use of the entire lot unfeasible, the owner could claim a taking of the entire lot. Similarly, if the owner could prove an existing and independently viable use for the buffer zone, such as operating a magazine stand next to the street, then she should be compensated for the opportunity cost of that magazine stand if its operation is completely prevented. ${ }^{98}$ Under no circumstances, however, should an

96 At least one lower court has considered the absence of independent economic viability in a parcel of land to preclude analysis of that parcel. See Twain Harte, $265 \mathrm{Cal}$ Rptr at 745 (stating that summary judgment against the landowner is justified if it is shown that "the 1.7-acre plot was not economically viable apart from the larger parcel").

97 See, for example, Gorieb v Fox, 274 US 603 (1927).

98 This example highlights the problem that would emerge if severance damages were allowed in regulatory taking cases as they are in physical taking cases. If severance 
owner of a city lot be compensated for what is in fact a diminution in value of the entire lot by alleging that the buffer zone had been completely taken. ${ }^{99}$

Undoubtedly, some definitional issues regarding the "independent economic viability" of a parcel will remain, just as they remain under the Lucas Court's phrase "all economically viable use." A simple question for a court to consider in arriving at an assessment of independent economic viability would be whether the property in question could profitably be put to use if it were the owner's only parcel. If the answer is yes, then the parcel should be considered independently. If the answer is no, however, the landowner should be required to propose a broader parcel for the denominator. The resolution of most cases under this test should be clear and predictable.

One possible criticism of this test is that it is highly manipulable by property owners because it depends on potential economic uses of property, rather than actual uses or expectations. An owner might simply assert that a piece of property has a particular economically viable use, such as for setting up concession stands, when in fact she had no intention of putting the land to such use. These sorts of claims, however, would be rare given that the property owner would bear the burden of proof as to each element.

First, the owner must prove that a particular parcel of land has the potential for economically viable use as an independent unit. A particular use must be more than merely feasible. Rather, it must produce positive economic benefits given all of the costs involved. Although this test ultimately depends on how the property could be used, a plaintiff will most easily prove the economic viability of a proposed use by demonstrating that that is how the property would be used. When a proposed use for a segment of property conflicts with its actual or presently intended use, the property owner would be forced to explain why he would forego

damages were awarded, a plaintiff could allege a seemingly minimal taking of a buffer zone and thereby receive compensation for the loss of value to his entire property interest. Because the standard of independent economic viability disregards a property owner's adjacent property interests in the initial regulatory taking inquiry, it should disregard it in awarding damages as well. In other words, by narrowing the focus to a particular segment of land, the plaintiff should be limited to receiving compensation only for loss of economic uses to which the land would have been put if it were his only segment of property.

${ }_{99}$ This would be analogous to the plaintiff's argument in Penn Central that a restriction on the ability to expand Grand Central Station was a taking of the air rights above the terminal. 438 US at 130. 
such economic gain. One possible explanation is that the parcel has even greater value as part of a larger group of property rights, but nevertheless could produce positive economic value as a single unit. ${ }^{100}$ Another possibility is that the opportunity has only recently emerged or been discovered. In any case, a landowner would have to convince a court by a preponderance of the evidence that the explanation is real and not simply crafted for the litigation.

The landowner would also have to prove a deprivation of all economically viable use due to the regulation under Lucas. This should in fact be a difficult burden, especially since the existence of a post-regulatory use for the property need not be independent of surrounding land interests (as with a potential use needed to prove substantiality). Thus, a building owner could not claim damages from a set-back ordinance for loss of magazine stand profits if in fact the operation of a magazine stand would lower the value of the entire lot. In such a case, the buffer zone obviously has substantial economic use to the building owner as open space, and would continue to have that use after the regulation. ${ }^{101}$

Although the test of independent economic viability would cause a significant reconceptualization of the denominator issue, it would not create a radical change in actual outcomes. Consider the case of Grand Forks-Traill Water Users, Inc. $v$ Hjelle, in which a North Dakota statute prohibited development of gas, water, oil, power, or communication lines within 100 feet of a state highway. ${ }^{102} \mathrm{~A}$ water company, which had purchased easements from various property owners to run a water line through lands near the highway, built the water line, and sued for com-

100 In many cases, this will be easy to prove. Often it is obvious that a piece of property is valuable and has real economic potential. It is only determining which use is most profitable that is difficult. It is property such as this, however, that clearly warrants Fifth Amendment protection.

${ }^{101}$ This is not to say that the mere existence of some scenic value of a piece of property to its owner will always defeat a taking claim. However, when the scenic value that a buffer zone adds to a building is significant enough that the building owner would clearly pay a substantial sum to have the buffer zone remain clear if needed, then a set-back ordinance cannot be said to have deprived an owner of all economic use of the buffer zone when he owns the building as well.

A similar difficulty arises under the Lucas test in determining whether the resale value of a piece of property is significant enough to constitute a viable economic use. For a recent discussion of this issue by the Federal Circuit, see Florida Rock Industries $v$ United States, 18 F3d 1560 (Fed Cir 1994) (vacating its previous decision because, even under a narrow view of the denominator, a reasonable resale value for the property remained).

102413 NW2d 344, 345-46 (ND 1987). 
pensation when the state ordered the water line moved. The Supreme Court of North Dakota held that no taking had occurred, invoking the nonseverability rule of Penn Central and Keystone. ${ }^{103}$ Although the court gives no indication as to what it considered to be the "parcel as a whole," it would likely have reached the same result under the standard of independent economic viability. The water company could not plausibly claim that the long strip of land from which it was forced to move its water line was "taken," for there would appear to be no use for the land independent of the water network. What good is a single stretch of a water line by itself? The company could widen the strip so as to claim that farming is possible on the land, but in so doing it would defeat its claim that all economically viable use was extinguished from the property. Finally, the company could not plausibly claim that its entire network of water lines had been taken, because those water lines farther away from the highway would maintain economic viability. Unless the statute was so restrictive as to put the entire water operation out of business, the company would have no valid taking claim.

The only cases in which the standard of independent economic viability would produce a different result are those in which a different result should occur. These cases include those such as Deltona Corp. $v$ United States ${ }^{104}$ and Ciampitti $v$ United States ${ }^{105}$ in which a developer purchases a large tract of land and the government prohibits development on only part of the original purchase. Where the total restrictions on development affect a significant enough segment of land that it could be independently developed for a profit, the principles of fairness and justice underlying the Fifth Amendment require that the owner be compensated for his loss. Such a case would in principle be no different than that of Lucas.

\section{CONCLUSION}

In his well-known dissent in San Diego Gas \& Electric Co. $v$ San Diego, Justice Brennan emphasized one of the most important reasons for applying the Takings Clause to restrictions on the use of private property:

103 Id at $346-47$.

104657 F2d 1184. See text accompanying notes 55-57.

$10522 \mathrm{Cl} \mathrm{Ct} \mathrm{310.} \mathrm{See} \mathrm{text} \mathrm{accompanying} \mathrm{notes} \mathrm{76-77.}$ 
From the property owner's point of view, it may matter little whether his land is condemned or flooded, or whether it is restricted by regulation to use in its natural state, if the effect in both cases is to deprive him of all beneficial use of it. From the government's point of view, the benefits flowing to the public from preservation of open space through regulation may be equally great as from creating a wildlife refuge through formal condemnation or increasing electricity production through a dam project that floods private property. ${ }^{106}$

Justice Brennan's justification for temporary regulatory takings not only led to the subsequent overturning of San Diego Gas \& Electric in First English, ${ }^{107}$ but was also instrumental to the Court's decision in Lucas. ${ }^{108}$ Similarly, the fact that an owner holds adjacent property which may still be developed, or considered his property as part of a larger parcel, should not bar his compensation for the lost property any more than if the state had taken the title to his lands. The standard of independent economic viability restores this basic intuition to the law. It also significantly improves the clarity and predictability of regulatory takings law. Finally, it provides a rational basis for assessing whether a citizen has been called upon to sacrifice too much in the interests of society, and for correcting those costs through just compensation.

106450 US 621, 652 (1981).

107482 US 304 (1987). See text accompanying notes 43-47.

108 Citing Brennan's dissent, the Court noted that "total deprivation of beneficial use is, from the landowner's point of view, the equivalent of a physical appropriation." Lucas, $112 \mathrm{~S} \mathrm{Ct}$ at 2894. 
, 